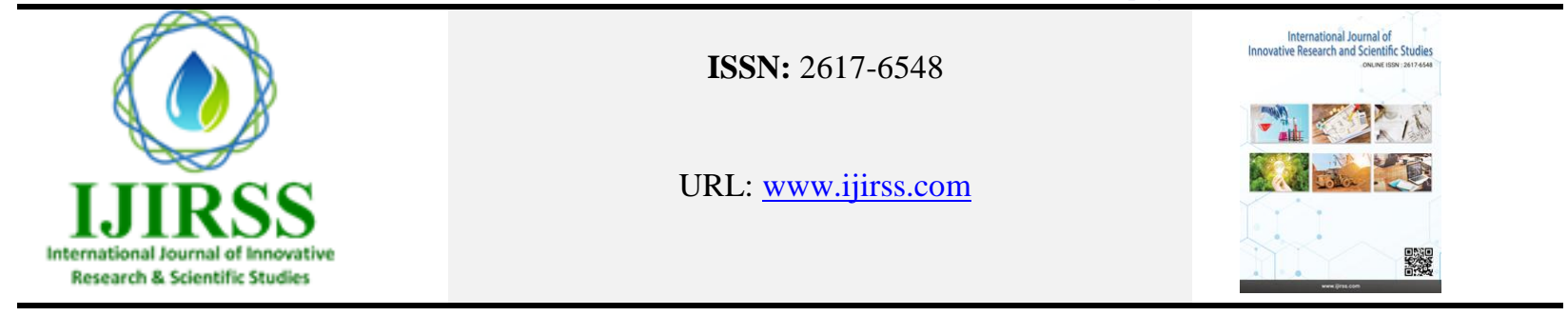

\title{
Anti-Corruption Tools of Financial Risk Management in Public Administration
}

Volodymyr Kopanchuk ${ }^{*}$, (D) Oleh Kravchuk², (D) Vadym Torichnyi³, (D) Anastasiia Metili, (D) Oleksii Kurtsev5, (DOlena Kopanchuk ${ }^{6}$

\begin{abstract}
${ }^{1,2}$ Criminal Law and Procedure Department, Leonid Yuzkov Khmelnytskyi University of Management and Law, Khmelnytskyi, Ukraine. ${ }^{3}$ National Security and Management Department, National Academy of the State Border Guard Service of Ukraine named after Bohdan Khmelnytskyi, Khmelnytskyi, Ukraine.

${ }^{4}$ Law and Social Work Department, Izmail State University of Humanities, Izmail, Ukraine. ${ }^{5}$ Department of Public Administration and Regional Economy, S. Kuznets Kharkiv National University of Economics, Kharkiv, Ukraine. ${ }^{6}$ Education Center, National University of Civil Protection of Ukraine, Kharkiv, Ukraine.
\end{abstract}

*Corresponding author: Volodymyr Kopanchuk (kop_1010@meta.ua)

\begin{abstract}
Every country is concerned with the problem of corruption. Selfish misuse of public office undermines the people's confidence in government and institutions, makes public policies less effective and fair, and misuses taxpayer funds that could be used to build schools, roads and hospitals. Financial risk management in public administration is based on risk assessments and finding tools to help influence them. To develop practical tools for financial risk management, the authors studied the economic practises that determine the features of financial risk assessment. They identified the elements that can motivate financial risks, including three stages of identification and analysis of risks, analyzed the main stages and indicators of assessing an organization's financial condition based on the balance sheet, produced a risk assessment algorithm and risk minimization methods in managing financial activities, and conducted a comparative analysis of financial risk assessment methods. Based on the Professional Integrity Framework proposed by the Organization for Economic Cooperation and Development, the authors developed basic measures to mitigate the potential negative consequences and proposed seven financial risk management tools for public administration. The proposed anti-corruption tools will help significantly reduce financial risks in public administration and corruption in general.
\end{abstract}

Keywords: Anti-corruption tools, Corruption, Corruption Perceptions Index, Financial risk, Public administration, Risk management.

DOI: 10.53894 /ijirss.v4i4.297

Funding: This study received no specific financial support.

History: Received: 3 November 2021/Revised: 7 December 2021/Accepted: 14 December 2021/Published: 29 December 2021

Licensed: This work is licensed under a Creative Commons Attribution 4.0 License $(\mathrm{cc}) \mathrm{EY}$

Acknowledgment: All authors contributed equally to the conception and design of the study.

Competing Interests: The authors declare that they have no competing interests.

Transparency: The authors confirm that the manuscript is an honest, accurate, and transparent account of the study was reported; that no vital features of the study have been omitted; and that any discrepancies from the study as planned have been explained.

Ethical: This study follows all ethical practices during writing. 


\section{Introduction}

At the international anti-corruption conference in 2015, the Ukrainian government announced plans to improve anticorruption legislation, as well as the methodology and quality of the investigation of corruption crimes. Subsequently, in December of that year, an independent body designed to supervise investigations of corruption (the Specialized AntiCorruption Prosecutor's Office) was formed. The realisation of the efficacy of such initiatives will be a crucial element in Ukraine's aspirations to join the European Union.

Financial risk management in public administration is based on effective risk assessment and using the necessary tools to facilitate them so that the organization can successfully exist in conditions of uncertainty in the global economy; it is necessary to properly assess the degree of financial risk and manage it.

\section{Theoretical Basis}

\subsection{Economic Essence and Concepts of Determining the Features of Financial Risk Assessment}

There are several approaches to defining "financial or investment risk".

The first approach: the risk of providing and consuming financial services is the probability of loss in their sale or consumption [1,2]. An investment or trust company that invests its clients in securities or other long-term financial assets, a pension fund that provides pension services, or an insurance company that insures a client's risks, may not receive the planned profit or lose a share of, or all of, its capital. Similarly, banks that provide loans or carry out foreign exchange transactions may lose their funds if they do not repay loans or suffer losses when foreign exchange rates change. The risk of this loss extends also to the consumers of financial services.

The second approach: the risk of providing financial services is the probability of not receiving the planned profit due to uncertainty [3-5]. There are other definitions of this term, but the most accurate is a combination of the first and second definitions, in which the risk is associated with uncertainty and the probability of loss.

It is crucial to identify the nature of the risk, namely:

- Recognize an economic event after which the risk is expected to arise or increase.

- Choose the evaluation method among the alternatives provided by the standards.

- Assess the objects of accounting (assets, liabilities, capital, income or expenses) that arose as a result of this business event.

- Reflect the occurrence in the accounts and the financial statements [5-7].

Risk identification is the process of identifying, researching and detailing risks that may affect the achievement of an organization's goals within a management system. This process includes identifying sources of risk, researching events, causes and possible consequences.

As a result of the changing economic environment, the emergence of new financial instruments and new technologies increases the impact of financial risks on the organization's intended results.

The onset of financial risk does not always lead to negative consequences [8-10], since the consequences of financial risk can be seen in both positive and negative results of financial activities, but in theory and economic practice, the level of financial risk is assessed primarily by the size of possible economic loss.

Characteristic features that may motivate financial risks are presented in more detail in Figure 1.

The factors considered in the assessment of the financial risks of the organization allow it to be defined as a result of choices made by the authorities that make financial and operational decisions, which is directed on avoidance of negative consequences at the occurrence of an event $[2,11]$. In this sense, financial due diligence has a significant impact on forecasts for the coming years as it provides its customers with the information necessary to minimize these risks.

\begin{tabular}{|l|}
\hline Economic nature; \\
\hline The objectivity of manifestation; \\
\hline The subjectivity of assessment; \\
\hline $\begin{array}{l}\text { The posjectivity of manifestation; } \\
\text { consequences; }\end{array}$ \\
$\begin{array}{l}\text { The main } \\
\text { of financteristics } \\
\text { risks }\end{array}$ \\
$\begin{array}{l}\text { Connection with financial flows both inside the } \\
\text { organization and outside it; }\end{array}$ \\
$\begin{array}{l}\text { Inability to determine the financial result when } \\
\text { making a management decision; }\end{array}$ \\
transaction.
\end{tabular}

Figure-1.

Characteristics of financial risks of the organization.

Risk analysis involves a qualitative and quantitative study of risks to manage them further.

There are three stages of identification and analysis of risks [Figure 2]. 


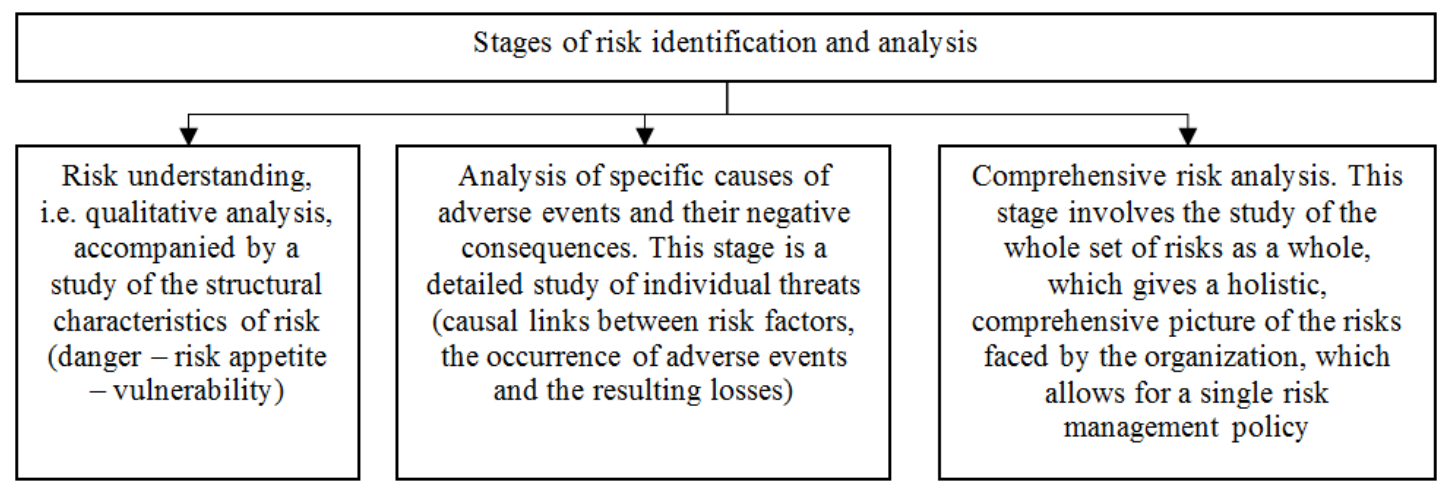

Figure-2.

Stages of analysis of financial risks of the organization.

The analysis of the organization's financial condition is carried out in stages, taking into account the nature and content of the updated balance sheet presented in Table 1.

Table-1.

The main stages and indicators for assessing the financial condition of the organization based on the balance sheet.

\begin{tabular}{l|l|l}
\hline The main stages of analysis & The economic essence of the indicator & $\begin{array}{l}\text { The leading indicators of } \\
\text { financial condition assessment }\end{array}$ \\
\hline $\begin{array}{l}\text { Analysis of the state of the } \\
\text { organization, industry, } \\
\text { macroenvironment }\end{array}$ & $\begin{array}{l}\text { Characteristics of the direction of } \\
\text { financial and economic activities of the } \\
\text { organization }\end{array}$ & $\begin{array}{l}\text { Statistical indicators for industry } \\
\text { evaluation }\end{array}$ \\
\hline $\begin{array}{l}\text { General analysis of the dynamics } \\
\text { of assets and liabilities of the } \\
\text { balance sheet }\end{array}$ & $\begin{array}{l}\text { Analysis of changes in absolute } \\
\text { balance sheet indicators and } \\
\text { assessment of trends. }\end{array}$ & $\begin{array}{l}\text { Series of dynamics of balance } \\
\text { indicators for 2-3 years }\end{array}$ \\
\hline $\begin{array}{l}\text { General analysis of the structure of } \\
\text { shsets and liabilities of the balance }\end{array}$ & $\begin{array}{l}\text { Analysis of changes in relative } \\
\text { indicators and balance sheet structure }\end{array}$ & $\begin{array}{l}\text { Graphic analysis of changes in } \\
\text { the structure of the balance } \\
\text { sheet }\end{array}$ \\
\hline $\begin{array}{l}\text { Liquidity analysis and assessment } \\
\text { settle its available current assets on its } \\
\text { liabilities }\end{array}$ & $\begin{array}{l}\text { Characteristics of the stability of the } \\
\text { financial condition of the organization, } \\
\text { which is provided by a high share of } \\
\text { ratio. Absolute liquidity ratio. } \\
\text { Liquidity ratio }\end{array}$ & $\begin{array}{l}\text { Coefficient of financial } \\
\text { independence. Coefficient of } \\
\text { economic dependence. Funding } \\
\text { ratio. } \\
\text { sinalysis and assessment of }\end{array}$ \\
\hline
\end{tabular}

We can distinguish the concept of risk assessment, which is carried out according to a specific algorithm, which consists of four steps Figure 3

\begin{tabular}{|l|l|}
\hline 1 & Determining risk probability parameter; \\
\hline $\mathbf{2}$ & Determining the level of materiality; \\
\hline $\mathbf{4}$ & Determining the parameter of the financial effect of risk; \\
\hline
\end{tabular}

Figure-3.

Algorithm for risk assessment.

There are two types of financial risk assessment: qualitative assessment, the main task of determining the factors and circumstances leading to the occurrence of risk situations, and quantitative assessment.

Since the process of risk assessment can not always be divided into independent stages, the most objective and accurate results can be achieved through qualitative and quantitative assessments. In addition, quantitative methods should be based on the standard methods of financial analysis which reflect the sectoral specifics of the financial and economic activities of organizations and serve as a basis for diagnosing the financial condition in crisis financial management.

Comparing the main methods of a quantitative assessment of financial risk, it can be seen that depending on the chosen assessment method, the level of risk may vary, and the observed outcomes of each method in terms of accuracy, simplicity of calculation, and information obtained indicate their suitability or unsuitability for autonomous use [Table 2]. 
The main task of the company's management is to reduce the degree of risk, which is typically assessed using the following methods:

- Diversification - a process of investing various objects of capital investment that are not related to each other. This type of neutralization is used to reduce income losses;

- Limitation - setting the maximum amount of losses from the occurrence of a risk, sale, or loan, a method most suitable for organizations specialized in lending and investment activities;

- Self-insurance - creating organizations that are most exposed to risks with an investment in special insurance funds. The latter is aimed at quickly overcoming small temporary difficulties to ensure continuous operation;

- Hedging - a method of agreeing to ensure the value of the organization's goods or profits and currency risks.

Table-2.

Comparative analysis of financial risk assessment methods.

\begin{tabular}{l|l|l|l|l|l|l}
\hline & & & & & & \\
Name of methods & & & & & \\
& & & & & \\
& & & & & \\
& & & &
\end{tabular}

Minimization of financial risks can be carried out by the methods given in Table 3.

The general risk management scheme is the same for any organization, enterprise, social system, or individual. It is based on traditional problem-solving methods.

Table-3.

Methods of minimizing risks in the management of financial activities of the organization.

\begin{tabular}{l|l}
\hline Method name & Characteristic \\
Risk localization & $\begin{array}{l}\text { The boundary of the system of rights and responsibilities so that the } \\
\text { consequences of risky situations do not affect the implementation of } \\
\text { management decisions. }\end{array}$ \\
\hline $\begin{array}{l}\text { Minimize risks or keep } \\
\text { risk within acceptable } \\
\text { limits }\end{array}$ & $\begin{array}{l}\text { Determining the minimum size of highly liquid assets of the organization, } \\
\text { setting the maximum amount of borrowed funds in business; }\end{array}$ \\
\hline Risk dissipation & $\begin{array}{l}\text { Setting the full amount of a deposit placed in one bank; limiting the } \\
\text { concentration of risks; obtaining from counterparties certain guarantees in the } \\
\text { provision of commercial loans and borrowings. }\end{array}$ \\
\hline Risk avoidance & Carried out by diversifying the activities of the organization. \\
\hline
\end{tabular}

Management of financial risks of the organization occupies an important place in the system of public administration.

\subsection{Anti-Corruption Tools in Public Administration}

Generally speaking, the idea of corruption and its practises can exist in any facet of society, although the levels of acceptance by the population vary depending on the social groups [12-15]. The common thing is that, in general, corruption itself is condemned in any culture, demonstrated by the fact that most countries have adopted anti-corruption legislation.

Despite a significant amount of scientific research and numerous international agreements to develop anti-corruption legislation, there is no universally accepted definition of corruption, though there are two particular definitions that are widely used. The description of the World Bank is often quoted: "Corruption is the abuse of state power for personal gain" [16]. Another report, which is cited more often than any other, has been proposed by Transparency International, a global non-governmental organization (NGO), against corruption: "abuse of power for personal gain" [17]. 
The World Bank definition relates to the relationship between the public sector and private interests, focusing on officials (civil servants, officials, bureaucrats, and politicians, etc.) - that is, anyone who makes decisions on public funds. Transparency International has expanded this definition. It covers any abuse of entrusted power in the private sector, for example, in the case of abuse of the trust of shareholders by a senior official of the company.

Common to the definitions of corruption by Transparency International and the World Bank (and others not listed here), an illegal gain must take place to qualify an act as corrupt.

Corruption as a phenomenon can be divided into several subspecies Figure 4.

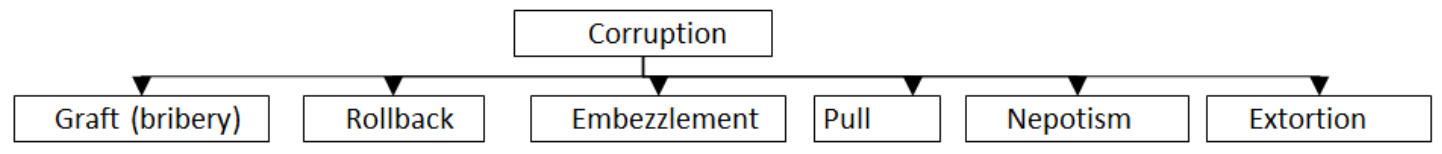

Figure-4.

Types of corruption.

Table-4.

Corruption perceptions index.

\begin{tabular}{|c|c|c|c|c|c|c|c|c|}
\hline Country & $\begin{array}{l}\text { CPI } \\
\text { score } \\
2020 \\
\end{array}$ & Rank & Country & $\begin{array}{l}\text { CPI score } \\
2020\end{array}$ & Rank & Country & $\begin{array}{l}\text { CPI } \\
\text { score } \\
2020 \\
\end{array}$ & Rank \\
\hline Denmark & 88 & 1 & Jordan & 49 & 60 & Ukraine & 33 & 117 \\
\hline New Zealand & 88 & 1 & Slovakia & 49 & 60 & $\overline{\text { Zambia }}$ & $\overline{33}$ & $\overline{117}$ \\
\hline Finland & 85 & 3 & Belarus & 47 & 63 & Niger & 32 & 123 \\
\hline Singapore & 85 & 3 & Croatia & 47 & 63 & Bolivia & 31 & 124 \\
\hline Sweden & 85 & 3 & Cuba & 47 & 63 & Kenya & 31 & 124 \\
\hline Switzerland & 85 & 3 & $\begin{array}{l}\text { Sao Tome } \\
\text { and Principe }\end{array}$ & 47 & 63 & Kyrgyzstan & 31 & 124 \\
\hline Norway & 84 & 7 & Montenegro & 45 & 67 & Mexico & 31 & 124 \\
\hline Netherlands & 82 & 8 & Senegal & 45 & 67 & Pakistan & 31 & 124 \\
\hline Germany & 80 & 9 & Bulgaria & 44 & 69 & Azerbaijan & 30 & 129 \\
\hline Luxembourg & 80 & 9 & Hungary & 44 & 69 & Gabon & 30 & 129 \\
\hline Australia & 77 & 11 & Jamaica & 44 & 69 & Malawi & 30 & 129 \\
\hline Canada & 77 & 11 & Romania & 44 & 69 & Mali & 30 & 129 \\
\hline Hong Kong & 77 & 11 & South Africa & 44 & 69 & Russia & 30 & 129 \\
\hline United Kingdom & 77 & 11 & Tunisia & 44 & 69 & Laos & 29 & 134 \\
\hline$\ldots$ & $\ldots$ & $\ldots$ & $\ldots$ & $\ldots$ & $\ldots$ & $\ldots$ & $\ldots$ & $\ldots$ \\
\hline Grenada & 53 & 52 & Mongolia & 35 & 111 & Korea, North & 18 & 170 \\
\hline Italy & 53 & 52 & $\begin{array}{l}\text { North } \\
\text { Macedonia }\end{array}$ & 35 & 111 & Libya & 17 & 173 \\
\hline Malta & 53 & 52 & Panama & 35 & 111 & $\begin{array}{l}\text { Equatorial } \\
\text { Guinea }\end{array}$ & 16 & 174 \\
\hline Mauritius & 53 & 52 & Moldova & 34 & 115 & Sudan & 16 & 174 \\
\hline Saudi Arabia & 53 & 52 & Philippines & 34 & 115 & Venezuela & 15 & 176 \\
\hline Malaysia & 51 & 57 & Egypt & 33 & 117 & Yemen & 15 & 176 \\
\hline Namibia & 51 & 57 & Eswatini & 33 & 117 & Syria & 14 & 178 \\
\hline Greece & 50 & 59 & Nepal & 33 & 117 & Somalia & 12 & 179 \\
\hline Armenia & 49 & 60 & Sierra Leone & 33 & 117 & South Sudan & 12 & 179 \\
\hline
\end{tabular}

A graft (bribery) is the payment of an improper benefit, such as a fixed amount, a percentage of a contract, or other non-monetary benefits, to a government official for that person to take specific actions or refrain from doing them in the performance of their official duties $[18,19]$.

A rollback is bribery, an illegal, secret payment made in response to a service provided; the term is used to describe the benefits derived from providing specific services.

Another form of corruption is embezzlement - an authorized official's theft of (government/public) resources. Unlike other forms of corruption, only one party is involved in the embezzlement. The authority holder can commit theft through the use of his public office to acquire, store and increase his personal wealth.

Favouritism (or pull, protection) is a process that results in the biased allocation of public resources. This includes giving positions or privileges to friends and family without regard to their qualifications. For example, in the political realm, allies can receive preferential terms to secure their support.

Nepotism (patronage to relatives) is a unique form of favouritism that embraces relatives and family members. Parts of the Balkans in Europe and some African states are often cited as examples of widespread nepotism, arising from the affinity for loyalty to one's family or clan, and the subsequent expectations of support. Favouritism and nepotism 
negatively affects democratic systems, as the employment of unskilled people is highly likely to negatively affect an organization's effectiveness. Favouritism and nepotism undermine faith in the fairness and impartiality of procedures and regulations. Nepotism and favouritism occur at both high and low levels of influence and power.

Extortion, like embezzlement, is a form of corruption in which only one party benefits. There is controversy as to what specific actions should be considered extortion. This is usually the name for a situation where there is a severe threat to a person's life, physical condition, or family. Racketeering is a typical example of extortion, using or threatening to use violence by military or paramilitary forces to seize money, and as a precondition for a company or individual to conduct business. The terms "blackmail" and "extortion" are often used interchangeably due to the use of extenuating circumstances in the criminal law in the case of extortion, though extortion is considered an extreme form of blackmail, in which the victim cannot get out without agreeing to the terms of the extortionist, while many cases of blackmail leave such an opportunity.

While corruption is a concern throughout the world, some countries are indicated as more susceptible to corruption than others [Table 4], though, as shown below, no country earns a perfect score [Figure 5].

Quantifying corruption is challenging for several reasons:

- Corruption, by its nature, is generally a secretive act, and neither side is interested in its publicity. This influences the answers given by respondents to the question about their involvement in corruption.

- Understanding corruption is not the same in different countries. The same behaviour may or may not be considered corrupt, and differences in understanding may exist within the same country, depending on the target group.

- The official figures for the number of sentences handed down by the courts in criminal cases on corruption show only one perspective - cases that have reached the court - and the number of undetected acts of corruption is unknown and difficult to estimate.

- There is a gap between perceived levels of petty corruption and the actual scale of said corruption; the public, as a rule, assesses higher levels of corruption than is typically defined.

CPI score 2020

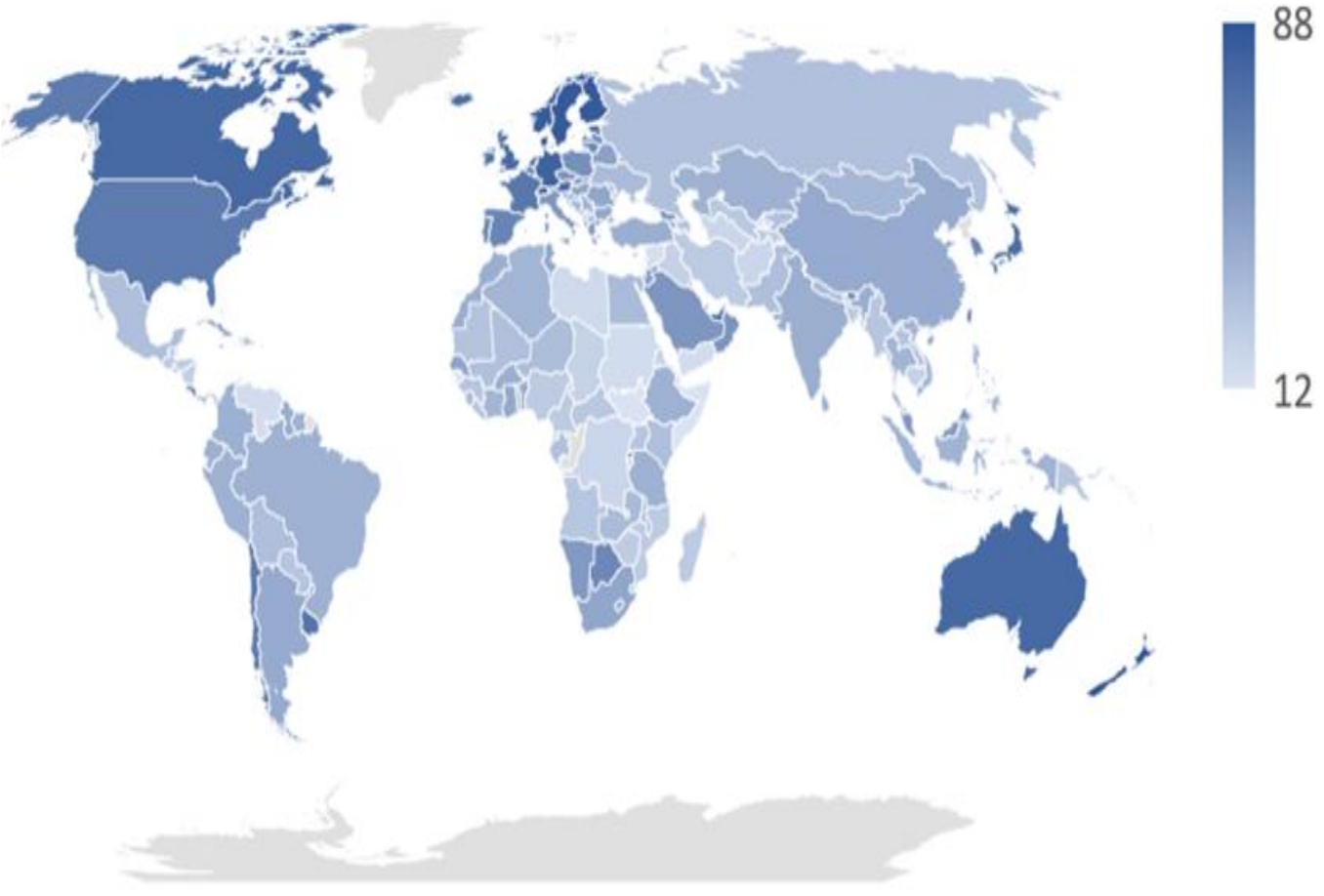

Figure-5.

Corruption perceptions index.

Source: according to data [17]. 


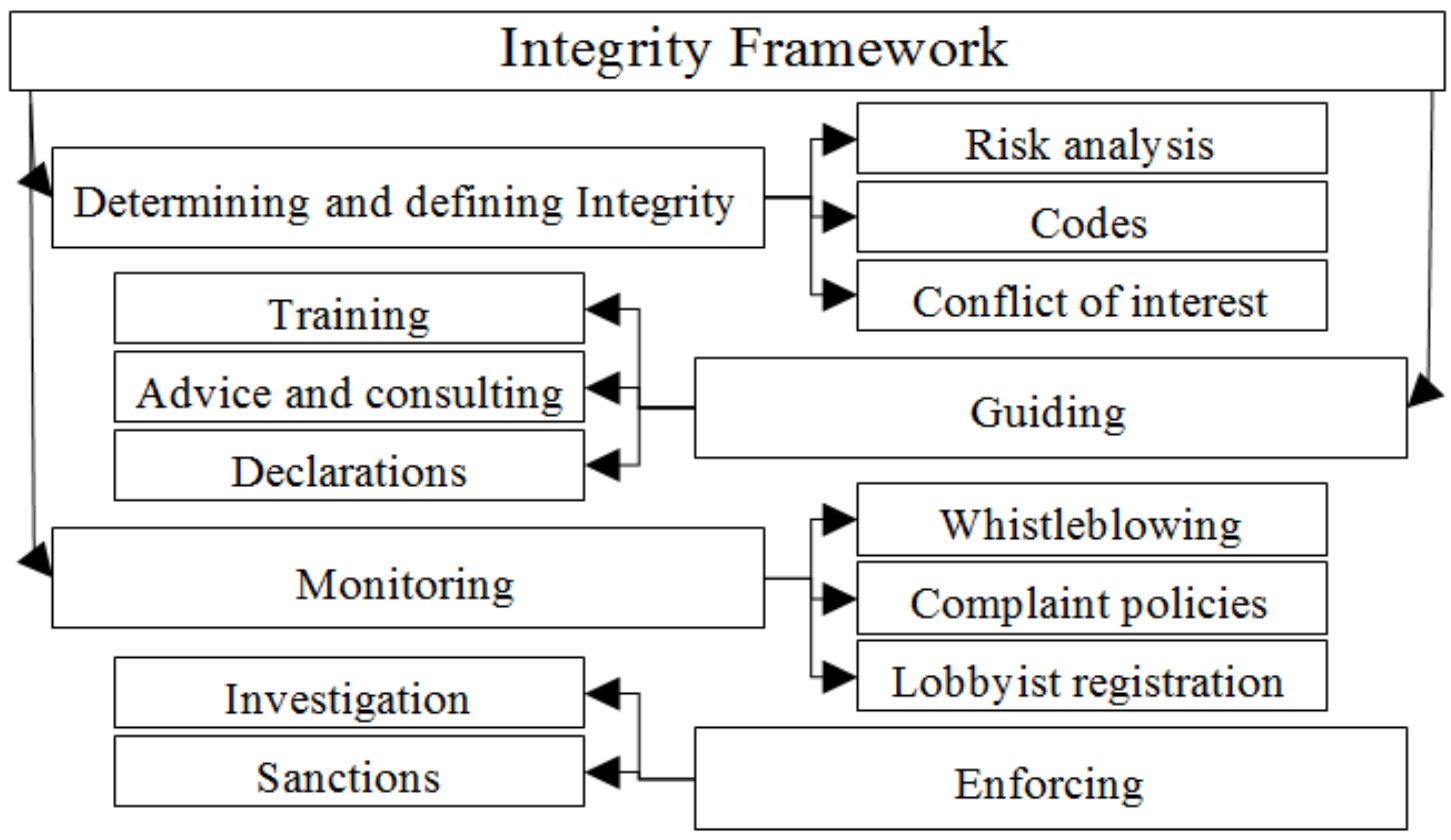

Figure-6.

The key components of an Integrity Framework

Source: according to data [16].

\section{Results and Discussion}

The Organization for Economic Co-operation and Development (OECD) has developed a framework since 2003 called the Integrity Framework [Figure 6].

Risk management policy is a set of forms, methods, techniques, and risk management methods. The purpose is to reduce the risk of making wrong decisions and reduce potentially negative consequences, which is implemented through the following basic measures [Figure 7].

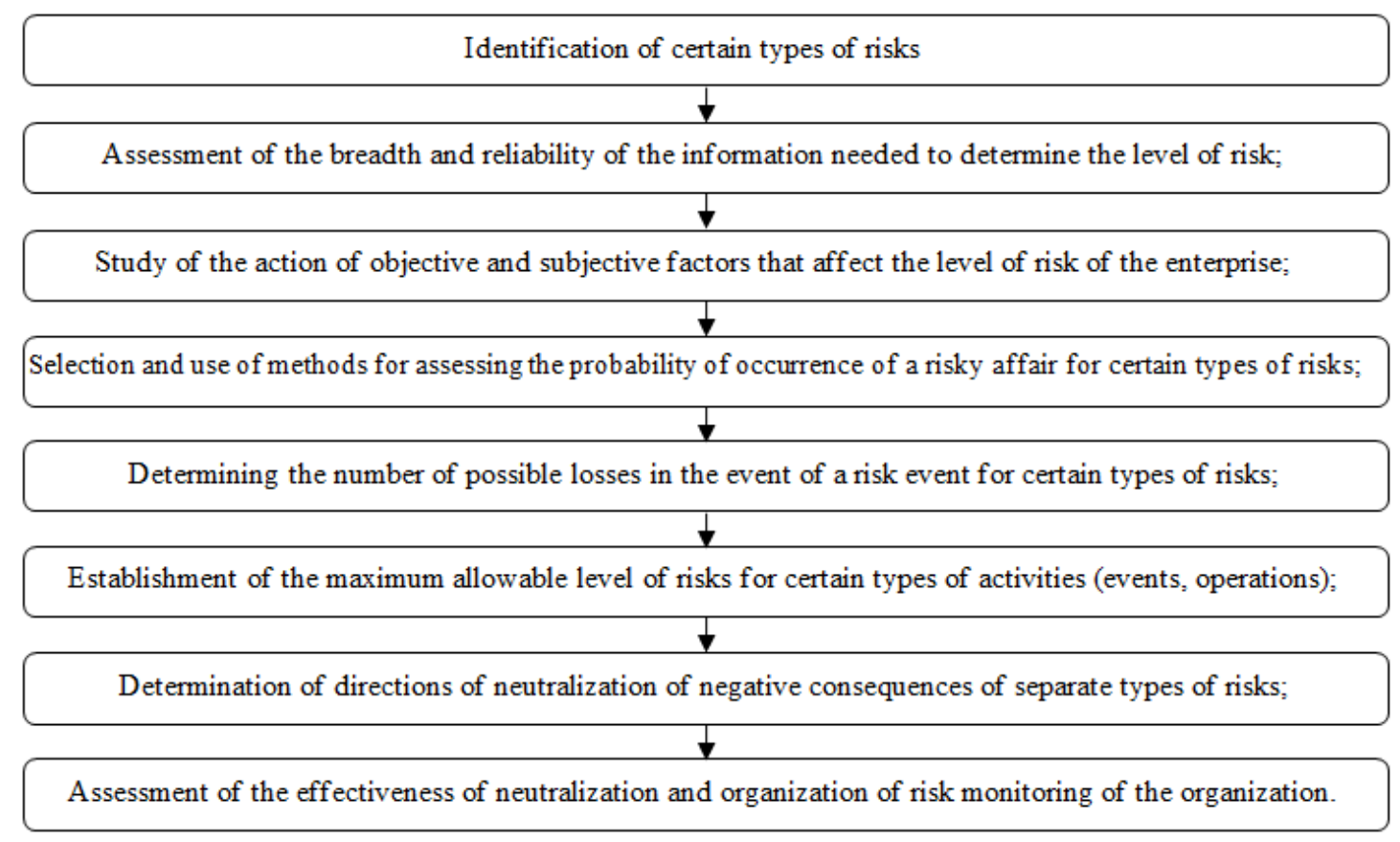

Figure-7.

Risk management policy. 


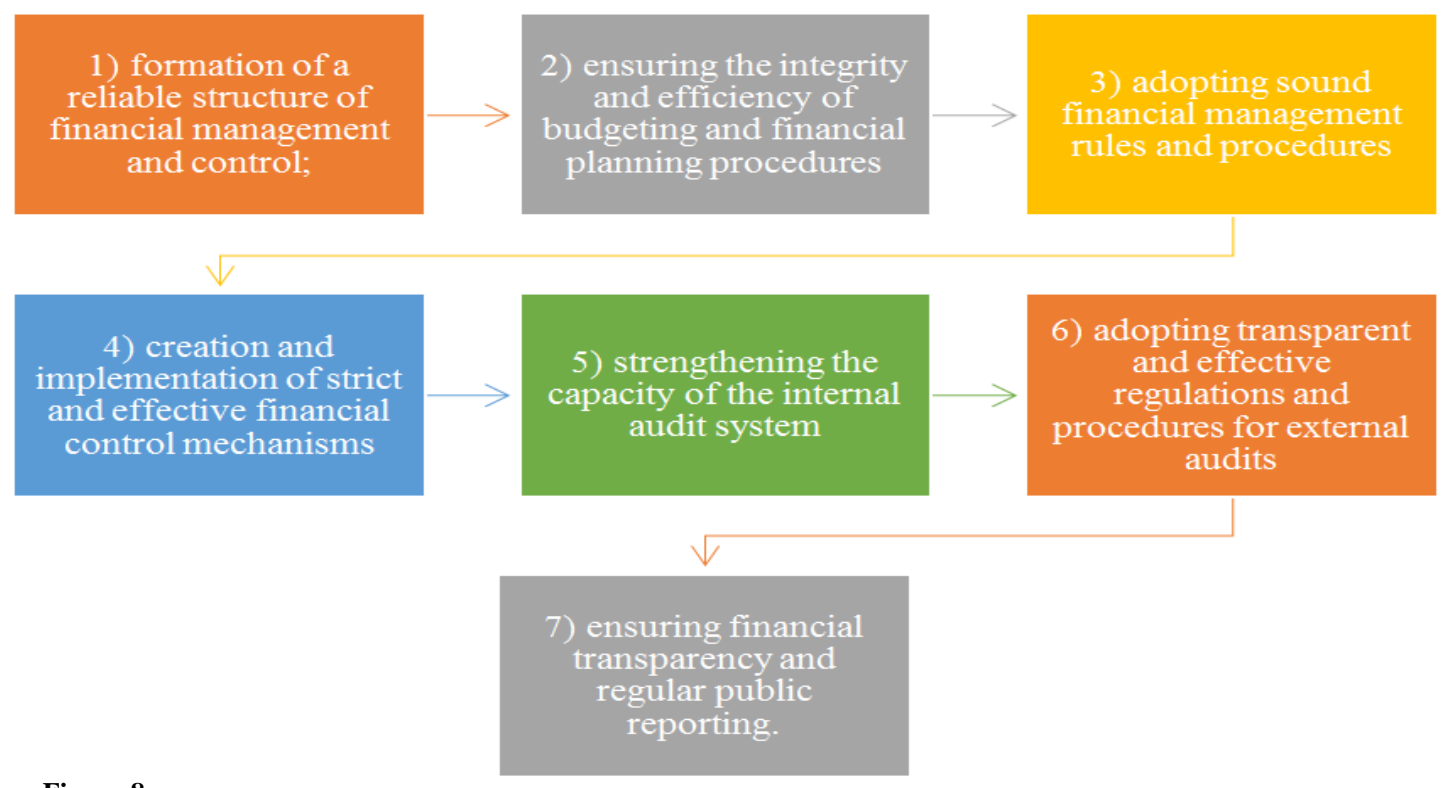

Figure-8.

Anti-corruption tools of financial risk management in public administration.

We offer seven tools for managing financial risks in public administration [Figure 8].

1) The organization must have solid and manageable financial management structures and systems, using clear and unambiguous control and reporting mechanisms. The organization should have the authority to centrally manage the capital budget in preparation for a significant event, though at the same time, professional and applicable national standards in the field of public finance management must be observed.

2) Ensuring the integrity and efficiency of budgeting and financial planning procedures. Public administration authorities face several particular difficulties in budgeting and financial planning. First is the uncertainty of the original requirements as well as the high probability of revisions and changes over the course of the procedure. Secondly, the need to consult with a wide range of stakeholders and partners (city municipalities, government departments) in a relatively short time frame, causing potential risks in the level of preparedness and human resources. Thirdly, it is necessary to consider the priorities in related areas of state policy: reducing harmful impacts on the environment, considering the impact on indigenous populations, environmental sustainability, and rational use of facilities after the end of the event. Fourthly, it is impossible to accurately predict costs and incomes at the initial stages due to factors such as market variations over the course of the procurement processes, and the demand for commercial services of the organization and income from their provision.

This necessitates periodic revisions of budgets, cost estimates, and revenue projections, as well as regular comparisons of budget execution against activities implemented and progress achieved. Maintaining the prestige of the organization and ongoing events and ensuring constant public support for its implementation requires strict adherence to the principles of openness when conducting audits, adjusting budgets, and approving changes. Cost projections found to be overestimated may indicate the inclusion of illegal commissions and bribes, though excessive expenditure can be caused by poor budget planning and financial management, as well as a lack of transparency.

3) Adopting good financial management rules and procedures. Public administration institutions are obliged to develop and take measures to ensure sound financial management. Organizations should clearly define and exercise the competencies and procedures for approving expenditures at all levels as a prerequisite for strengthening budget control mechanisms. Organizations should have clear criteria for the approval of costs in instances such as receptions and entertainment, travel, consulting, and remuneration of professionals and experts. There must be clear rules and procedures for approving such expenses and other significant expenses. Imperfect financial management rules and practises create favourable conditions for corruption, abuse, and increased financial risks.

4) Creation and implementation of strict and effective financial control mechanisms. A clear sign of an organization's vulnerability to threats of corruption and fraud is insufficient attention to issues identified during an internal audit. Organizations should take effective measures to ensure the safety of books, records, financial statements, and other documents related to public expenditures and revenues and prevent the falsification of such documents. Internal control systems, particularly the organization of accounting and reporting, should be subject to periodic review to ensure the reliability and efficiency of such systems. A financial oversight committee may be created from senior management within the organization.

5) Strengthening the capacity of the internal audit system. Regular inspections and internal audits should be carried out by experts who have received appropriate practical training and can identify suspicious transactions, bribery, possible fraud, clear conflicts of interest, and other financial risks.

6) Adoption of transparent and effective regulations and procedures concerning external audits. Government-appointed independent auditors should have unrestricted access to all financial transaction records. 
7) Ensuring financial transparency and regular public reporting. Accountability and transparency are two of the best antidotes to corruption. Public administration institutions should actively promote the transparency of budget planning and financial management procedures for making critical decisions that affect the financial stability (and by extension its viability) of the organization. They should take measures to facilitate the submission of frequent and reliable financial reporting to public authorities as part of a broader effort to increase transparency about major public events. Financial information must be publicly disclosed at all stages.

We believe that the proposed anti-corruption tools will help significantly reduce financial risks in public administration and corruption in general.

\section{Conclusions}

Corruption undermines the ability of the state to provide economic growth for the benefit of all citizens, and leads to the waste of taxpayers' funds, and weakens all spheres of citizens' lives, so it is necessary to improve anti-corruption tools for managing financial risks in public administration. This task requires challenging, tireless work in many facets, but to considerable benefit to the organization and to the public to which it serves. The implementation of such methods will require political will, continuous institutional strengthening to ensure greater integrity and accountability, and global cooperation.

\section{References}

[1] T. Dobina, K. Haidukevych, S. Panchenko, I. Petrova, and J. Sabadash, "Effectiveness analysis of entrepreneurship model of development qualities of future managers," Journal of Entrepreneurship Education, vol. 22, pp. 1-6, 2019.

[2] K. Shukla, "Project appraisal under risk, threat and uncertainty: A case study of the afforestation project of Bihar, India," Thesis (Ph. D.), University of Wales (U.C.N.W., Bangor: Dept. of Forestry and Wood Science, 1996.

[3] N. Podolchak and I. Kulynyak, "The method of complex estimation of risk level for lessor enterprises," Actual Problems of Economics, vol. 142, pp. 144-157, 2013.

[4] O. Karyy and O. Knjazevska, "Tasks prioritization of strategic planning of cities development: Experts' approach," Economics and Sociology, vol. 2, pp. 58-66, 2009.

[5] H. Beth, "Trademark registration can provide financial services companies with valuable benefits " Journal of Investment Compliance, vol. 11, pp. 59-61, 2010.Available at: https://doi.org/10.1108/15285811011030202.

[6] I. R. Abdrakhimov and L. E. Altynbaeva, "Controlling financial risks," Trends in the Development of Science and Education, vol. 67, pp. 6-9, 2020.

[7] M. Poplavskyi, "Entrepreneurship in the field of art business in the European union," Journal of Entrepreneurship Education, vol. 22, pp. 1-6, 2019.

[8] B. Crona, C. Folke, and V. Galaz, "The anthropocene reality of financial risk," One Earth, vol. 4, pp. 618-628, 2021.Available at: https://doi.org/10.1016/j.oneear.2021.04.016.

[9] S. Jiraskova, "Financial risk management," Land Forces Academy Review, vol. 22, pp. 276-280, 2017.Available at: https://doi.org/10.1515/raft-2017-0037.

[10] S. Abdo and D. Edgar, "Facing the challenges of Covid-19 in the Egyptian banking sector: the role of bricoleurs in achieving organizational innovations via learning through improvisation," Journal of Social Economics Research, vol. 8, pp. 77-95, 2021.

[11] M. Althof and W. Hardle, "FRM financial risk meter," Econometrics, vol. 42, pp. 1-35, 2020.

[12] E. Abu-Shanab and Y. Al-Zo'bie, "Government as an anti-corruption tool: Citizens perceptions," International Journal of Electronic Governance, vol. 6, pp. 232-248, 2013.Available at: https://doi.org/10.1504/IJEG.2013.058410.

[13] S. K. Antwi, Y. Kong, M. Mohammed, M. Donkor, and H. Kasim, "Does corruption grease or sand the wheels of economic growth in Ghana? An ARDL bounds test," The Economics and Finance Letters, vol. 7, pp. 162-178, 2020.

[14] O. F. Ogunlana, "Determinants of public sector corruption in Nigeria," International Journal of Public Policy and Administration Research, vol. 6, pp. 1-11, 2019.

[15] J. Muzurura, "Causes, dissemination channels, and consequences of corruption in Zimbabwe: Searching for a Kryptonite solution," Humanities and Social Sciences Letters, vol. 7, pp. 104-122, 2019.

[16] Organisation for Economic, "Organization for economic cooperation and development. Retrieved from: https://www.oecd.org/gov/44462729.pdf," 2009.

[17] Transparency International, "Corruption perceptions index 2020. Report. Retrieved from: https://www.transparency.org/en/cpi/2020/index/nzl," 2020.

[18] I. Kichuk, "The role of the university in the social and cultural creativity of the local society (Budzhak region)," Danubius, vol. 35, pp. 313-320, 2017.

[19] K. Cocka and I. Rusi, "The role of criminal law as an anti-corruption tool in the public sector," Academic Journal of Interdisciplinary Studies, vol. 5, pp. 99-110, 2016. 